\title{
ВПЛИВ БРЕНДУ НА ПОВЕДІНКУ СПОЖИВАЧІВ В УМOBAX COVID-19
}

\section{THE BRAND INFLUENCE ON CONSUMER'S BEHAVIOR IN THE ONDITIONS OF COVID-19}

\author{
Лихолат Світлана Михайлівна \\ кандидат економічних наук, доцент, \\ Національний університет «Львівська політехніка» \\ ORCID: https://orcid.org/0000-0002-0517-6852 \\ Задоріжна Інна Марія Володимирівна \\ студентка, \\ Національний університет «Львівська політехніка» \\ ORCID: https://orcid.org/0000-0002-4440-6550 \\ Lykholat Svitlana, Zadorizhna Inna Mariia \\ National University «Lviv Polytechnic»
}

\begin{abstract}
Метою статті є аналіз впливу COVID-19 на споживацькі можливості покупців та впливу бренду на їх рішення про здійснення покупки. Розкрито роль маркетингових досліджень у процесі вивчення поведінки купівельної поведінки споживачів. Охарактеризовано бренд як фрактор, який обирають при здійсненні покупки. Проаналізовано результати досліджень відомих компаній за обраною тематикою та зроблено узагальнюючі висновки щодо споживацької поведінки. Структуровано фрункції бренду, що впливають на поведінку споживачів. Представлені результати власних досліджень щодо готовності нести додаткові витрати споживачами у момент придбання товарів відомих брендів та її емоційної складової. Надано рекомендації щодо збереження конкурентних позицій брендом та впливу на вибір споживача в момент прийняття рішення про придбання товару або послуги.
\end{abstract}

Ключові слова: бренд, купівельна поведінка споживача, цільова аудиторія, брендинг, функції бренду, COVID-19.

Целью статьи является анализ влияния COVID-19 на потребительские возможности клиентов и влияние бренда на их решение о покупке. Раскрыта роль маркетинговых исследований в процессе изучения покупательной способности потребителей. Проведена характеристика бренда как фактора, который учитывают во время проведений покупки товара. Анализируются результаты исследований известных компаний по теме исследований и сделаны общие выводы о поведении потребителей. Структурированы функции бренда, влияющие на поведение потребителей. Представлены результаты собственных исследований о готовности потребителей нести дополнительные расходы на момент покупки товаров известных брендов и их эмоциональной составляющей. Даны рекомендации по поддержанию конкурентных позиций бренда и его влиянию на выбор потребителя в период принятия решения о покупке товара или услуги.

Ключевые слова: бренд, поведение потребителей, целевая аудитория, брендинг, функции бренда, COVID-19.

The purpose of the article is a topical issue that requires an analysis of the impact of COVID-19 on consumer's opportunities, as well as determining the influence of a brand on the buyer's final decision to make a purchase. The role of marketing research in the process of studying consumer's behavior is revealed and defined that rising prices and counterfeits, as well as reducing the quality of products have an impact not only on the health of consumers, but will have negative consequences for manufacturers by decreasing consumers' loyalty. In such circumstances, companies need to implement effective marketing measures aimed at social responsibility. A brand is described as a factor that is chosen when making a purchase and the one that can have different strengths depending on the place of purchase (online or offline). The researches results of known companies on the chosen subject are analyzed and the generalized conclusions concerning consumer's behavior are made. The brand functions that influence consumer's behavior are structured and it is established that they contribute to the identification of the product, reduce the time for purchase, guarantee compliance with quality parameters, personalize the purchase, 
form a sense of confidence and stability. The results of our own research on the willingness to bear additional expenses by consumers at the time of purchase of well-known brands and its emotional component are presented. It is established that the positive experience of one consumer can influence the decisions of others to buy. Buyers believe that an influential brand provides a more successful launch of a new product on the market, because consumers are more willing to try a new product presented by a well-known brand. It is noted that the brand as well as society is changing and focusing on innovation. At the same time, consumer's behavior is modified as well as the activities of companies that should aim to build consumer-brand relationships. Recommendations for maintaining the competitive position of the brand and methods of influencing consumer's choice at the time of the decision to purchase a product or service are made.

Keywords: brand, consumer's buying behavior, target audience, branding, brand functions, COVID-19.

Постановка проблеми у загальному огляді. На сьогоднішній день конкурентне середовище на ринку є надзвичайно розгалуженим. Пандемія відчутно вплинула на низку галузей через що адаптація до нових умов господарювання є важливим фрактором під час COVID-19. Компанії вводять інновації, щоб виділятись та зацікавлювати споживачів. З'явилась значна кількість одноманітних підприємств, що пропонують схожу, а часто і однакову за характеристикою продукцію. Тож, посісти ключові позиції на ринку допоможе бренд-менеджмент, адже імідж та репутація виробника суттєво впливають як на просування товару, так і на фрормування споживацьких вподобань. Застосування едрективних інструментів стратегії маркетингової комунікації сприятиме підвищенню лояльність клієнтів. Побудова довгострокових відносин з споживачами збільшать прибутковість та $є$ одним з найпопулярніших способів збільшення ринкової вартості бренду.

Аналіз останніх досліджень і публікацій. Обрана тема була досліджена багатьма науковцями. Дослідження щодо впливу бренду на поведінку споживача та його роль у процесі маркетингових комунікацій проводили Семенихін П. [1], Мокшанцев Р. [2], Карпова С.В. [3]. Тоді як, Амблер Т. і Берроу С. [4] розглядали питання бренду роботодавця та стверджували, що саме цей вид бренду $\epsilon$ важливим при оцінюванні впливу бренду на споживача. Сартейн Л. та Шуманн М. [5] зазначали, що у формуванні бренду важливу роль відіграє людський фрактор. Тож, питання брендингу $€$ досить цікавим та актуальним, особливо, за умов пандемії і потребує більш глибокого дослідження.

Формулювання цілей статті (постановка завдання). Метою статті $€$ визначення пріоритетних фракторів, які мають вплив на фрормування рішення споживача про придбання товарів певного бренду в умовах, які виникли під дією COVID-19.

Виклад основного матеріалу. На даний момент постало гостре питання, яким чином
COVID-19 вплинув на купівельні можливості споживачів та як стимулювати попит на товари. Пандемія скоротила витрати населення на значну частину продукції. За результатами досліджень, які проведено компанією KPMG у 12 країнах світу, 40\% респондентів змушені зменшити свої витрати через фрінансові труднощі, а 13\% відкладають великі покупки. При здійсненні покупки споживачі у $40 \%$ зосереджують увагу на особистій безпеці, 37\% - на асортименті товарів та послуг і 35\% враховують попередній досвід. Прямому зв'язку особистих цінностей з брендом та соціальній поведінці при виборі приділяють увагу відповідно на $19 \%$ та $18 \%$ [6].

У складній епідеміологічній та економічній ситуації виробникам товарів та послуг, які вже зазнали величезні втрати, важливо пам'ятати про соціальну відповідальність. Перш за все, це стосується виробників продуктів харчування, засобів гігієни та ліків. Зростання цін і фральсиорікатів, а також зниження якості виробленої продукції в результаті вплинуть не лише на здоров'я споживачів, але і негативно позначиться на виробниках, тому що довіру та лояльність споживачів важко втримати. За таких обставин підприємствам необхідно запровадити ефективні маркетингові заходи скеровані на соціальну відповідальність.

За умов пандемії споживацькі можливості скоротились. До прикладу, 24\% українців почали здійснювати покупки у тих брендів, які правильно відреагували на поточну ситуацію 3 коронавірусом. Українці більше половини бюджету витрачають на продукти харчування (30\%) та обов'язкові платежі (30\%). До прикладу, в регіональному розрізі жителі центральних областей витрачають на продукти харчування та обов'язкові платежі 31\% і 32\%, східних областей 32\% і 31\%. Найменше - жителі Києва та Київської області (30\% і 27\% відповідно). COVID-19 вплинув на споживацькі звички 63\% українців, так зазначає у своєму дослідженні компанія Deloitte [7]. При зміні купівельної активності 45\% україн- 
ців здійснюючи покупки орієнтуються на безпечність торгової марки. Так як відомі бренди мають удосконалені онлайн платорорми це сприяє більш успішному здійсненню інтернетпокупок. 32\% респондентів за умов карантину планують більше купувати в онлайн магазинах. Карантин змінив погляди споживачів на інтернет-покупки, більшість звертається до надійних та провірених брендів. Крім того, компанія Deloitte стверджує, що 64\% українців враховують вплив бренду під час здійснення покупки в офрлайн-магазині $(72 \%$ в онлайнмагазині); 74\% респондентів продукти харчування родичам, друзям та знайомим, тоді як в онлайн-магазині 68\%; при виборі одягу та взуття в офрлайн-магазині рекомендують $76 \%$ і відповідно 75\% онлайн; при виборі товарів домашнього вжитку та побутової хімії, відповідно рекомендують, 68\% офрлайн-покупки та $66 \%$ онлайн.

Бренд, як визначальний фрактор при здійсненні офрлайн-покупок алкогольних напоїв враховують $70 \%$ українців і $22 \%$ онлайн-покупок; при виборі косметичних засобів та парсрумерії 72\% і 77\% відповідно; при виборі дитячих товарів 63\% і 69\%; при виборі електроніки та побутової техніки 78\% і 84\%; при виборі меблів та товарів для дому 58\% і 64\%; при виборі лікарських засобів 69\% і 72\%, відповідно [7]. Найбільше піддаються впливу бренду покупці у віці 16-29 років (23\%).

Слід зауважити, що COVID-19 привів не лише до зміни в споживчих трендах але й до змін в окремих галузях промисловості. На початку 2020 року незалежна міжнародна компанія Euromonitor International опублікувала глобальне дослідження Top Global Consumer Trends 2020 та визначила нові споживчі тренди на споживчих ринках. Компанія акцентувала увага на зміні бізнес-стратегій компаній в найближчі роки в усьому світі. Поява нових споживчих тенденцій, в тому числі, обумовлює зміни у пріоритетних напрямах інвестиційної діяльності [8]. COVID-19 вплинув на емоційний стан споживача через що постійний зв'язок 3 ним вимагає відкритої комунікації. Тож бренди можуть проявити себе і з'ясувати свою справжню цінність в очах цільової аудиторії, створювати корисний та лаконічний контент, нарощувати лояльність споживачів та створювати доступ до продукту через онлайн покупки. Аналізуючи опитування компанії Valassis виявлено, що в будь-якому випадку, в обставинах COVID-19, лояльність до брендів така [9]: 48\% респондентів обирають відомі їм бренди, 21\% нама- гаються змінити відомі бренди, але в основному обирають відомі, 13\% пробують знайти для себе нові бренди, 19\% є менш до бренду обираючи більш доступні. Водночас, 48\% зазначили, що не сподівалися що їм потрібно буде колись вимушено змінити бренд. Такий досвід може привести до довгострокових змін в купівельних моделях споживачів.

Пандемія вплинула на доволі широкий спектр брендів. За загальними підсумками 20\% вартості бренду втратили товарні марки одягу. Також постраждали авіаперевезення, туристичні послуги, ресторани та готелі, публічні заходи та інші категорії для яких гостро постає питання адаптації стратегії. Міжнародна ізоляція зробила практично неможливим споживання пропонованих ними благ і навіть після зняття обмежень втрати в цих галузях не будуть компенсовані.

Скорочення споживацьких можливостей привело до закриття значної частини компаній. Водночас, ті що встигли себе зарекомендувати на ринку та завоювати довіру споживачів освоюють нові сегменти ринку та збільшують обсяги збуту. Бренд фрактично виконує роль культуроутворюючого чинника, впливає на фрормування життєвих принципів підростаючого покоління шляхом демонстрації та нав'язування певних цінностей або заборон, а також стимулює певний тип поведінки цільової аудиторії [10].

В процесі прийняття рішення про купівлю певного продукту споживач використовує порівняльні кількісні та якісні методи, керуючись фрункціональними характеристиками товару та чуттєво-емоційним сприйняттям, які формує у його свідомості бренд. Тож, товари відомих брендів виконують поведінкові фрункції, які призначені для полегшення процесу прийняття рішення про придбання товару та дають змогу скоротити час на його придбання. Основними функціями бренду, що впливають на поведінку споживачів $€$ : фрункція престижу, інфрормаційна, надійності, лояльності, довіри до бренду, доступності, поширеності, задоволення від бренду. Функції бренду сприяють ідентифікації товару, скорочення часу на придбання, закріплюють практичність, гарантують дотримання якісних параметрів, персоналізують покупку, фрормують почуття впевненості та стабільності, пізнаваність.

Завдання бренду товарів, представлених на масовому ринку, передбачає виконання перерахованих фрункцій, щоб бути естетично привабливими та демонструвати соціальновідповідальне ставлення до навколишнього 
середовища. Також бренд дозволяє: підтримувати запланований обсяг продажів на обраному ринку та реалізувати довгострокові програми закріплення у свідомості споживачів; забезпечити збільшення прибутковості внаслідок розширення асортименту та поширення інсормації про унікальні якості нового товару; здійснити передачу інсрормації в рекламних матеріалах та кампаніях про традиції, культуру країни, регіону, міста, де виробляються товари, враховуючи запити споживачів, для яких вона призначена, а також особливості території, де вона продається. Покупці бажають отримувати провірений продукт та схильні придбати товар відомих брендів розуміючи, що вони нестимуть додаткові фрінансові витрати (табл. 1).

Отже, позитивний досвід одного споживача може вплинути на рішення інших про покупку. Покупці вважають, що впливовий бренд забезпечує більш успішний старт нового товару на ринку, адже вони швидше готові спробувати новий товар, представлений відомим брендом.

Суспільство змінюється та орієнтується на новації, які виходять на ринок внаслідок чого, поведінка споживачів модиорікується які діяльність компаній, які повинні концепції побудови відносин споживачів-брендів: вподобання покупців та залучення клієнтів. Перш за все, необхідно звернути увагу на те, як відносини між споживачами-брендами продовжують розвиватися. На даний час, вплив на споживачів здійснюється через засоби масової інорор- мації, соціальні мережі, рекламу. $€$ певний перелік товарів, які бажає отримати кожен. Наприклад, розглядаючи сореру ювелірних прикрас, одним із найпопулярніших сьогодні $€$ бренд Pandora. Серед смартфонів найбільшим попитом користується продукція компанії Apple. У сорері одягу на ринку серед вікової категорії 25-30 років найпопулярніші бренди: Fendi, LouisVuitton, Gucci, Dolce\&Gabbana, Prada, Versace, TheNorthFace. Однак, не всі бренди мають однакову важливість для споживачів. Важливе значення має те, як споживач сприймає продукт. Емоції, які приходять в перші секунди, відіграють ключову роль при прийняті рішення про покупку (табл. 2).

Отже, сприйману якість можна пояснити тим як реалізуються очікування споживача щодо конкретного товару чи компанії. Формуючи бренд необхідно фрормувати конструктивний імідж та готовність клієнтів додатково платити за нього де ціна підтверджуватиме лояльність споживача. Бренди, які мають більш високу сприйняту цінність, призводять до фрормування тривалих відносин між брендом та споживачами [11].

Важливо знати при яких умовах та причинах погляди на бренд у потенційних споживачів можуть змінитись. Бренд досягає успіху, коли робить культурний прорив. А, брендинг $\epsilon$ набором прийомів, призначених для створення соціальної течії. Цифррові технології створили не лише потужні інтернет мережі, але й кардинально змінили принцип дій сус-

Таблиця 1

\section{Фінансові витрати споживачів у момент придбання товарів відомих брендів}

\begin{tabular}{|c|c|c|}
\hline Переплата за бренд & \begin{tabular}{|l|} 
72\% готові заплатити \\
20\% додаткової ціни за бренд
\end{tabular} & $\begin{array}{l}\text { Для 25\% ціна не важлива, якщо } \\
\text { це бренд який вони знають }\end{array}$ \\
\hline $\begin{array}{l}\text { Орієнтація на провірений } \\
\text { бренд }\end{array}$ & 70\% орієнтуються на бренд & $\begin{array}{l}\text { У } 50 \% \text { вирішальним в момент } \\
\text { покупки є бренд }\end{array}$ \\
\hline $\begin{array}{l}\text { Рекомендації } \\
\text { та популярність бренду }\end{array}$ & \begin{tabular}{|l|} 
60\% вивчають наявну \\
інфрормацію про бренд перед \\
здійсненням покупки
\end{tabular} & $\begin{array}{l}\text { 30\% приймають рішення про } \\
\text { покупку товару певного бренду } \\
\text { за рекомендаціями знайомих }\end{array}$ \\
\hline
\end{tabular}

Джерело: результати власних досліджень

Таблиця 2

Емоції, які отримує споживач в момент прийняття рішення про здійснення покупки

\begin{tabular}{|c|c|}
\hline Якість продукції & Якість обслуговування \\
\hline Безпечність & Лояльність \\
\hline Відповідність специсікації & Надійність \\
\hline Особливість & Симпатія \\
\hline Справність & Компетентність \\
\hline 至 & Обізнаність \\
\hline Привабливість & Достовірність \\
\hline Надійність &
\end{tabular}

Джерело: результати власних досліджень 
пільства. Крауд маркетинг в певній мірі тісно пов'язаний 3 просуванням брендів, адже це ретельний аналіз цільової аудиторії для будьякого об'єкта маркетингу, що позиціонується в соціальних мережах, блогах, форумах певної тематики, а також в анкетах. Тож власникам бренду необхідно використовувати даний спосіб комунікації з споживачами аби вплинути на їх поведінку та вибір. Бренд може підтримати свою культурну значимість, відтворюючи особливо інтригуючі або суперечливі питання, які домінують у медійному дискурсі, пов'язаному з ідеологією. Однак, бренд - це не лише обіцянка для клієнта. Він повідомляє їм, що вони можуть очікувати від бренду, фрормує відмінності у пропозиціях, які надають конкуренти, здійснює вплив на поведінку споживача та спонукає його до прийняття рішень про покупку.

Послідовне стратегічне брендування призводить до значної відомості бренду та формує вартість самого бренду. До прикладу, компанія Coca-Cola створила потужний капітал бренду та продає продукцію за тою ціною, яку формує особисто i, водночас, задає цінову планку конкурентам. Компанія Nike пов'язує свою продукцію із зірковими спортсменами, сподіваючись, що клієнти перенесуть свою емоційну прихильність від спортсмена до продукту. Кожна успішна компанія використовує власний бренд, оскільки він впливає на споживача та допомагає компанії передати своє бачення та встановити зв'язок з цільовою аудиторією. У нестандартних умовах господарювання викликаних COVID-19 бренд став необхідною умовою підтримки стабільної позиції фрірми та одним із основних чинників підвищення конкурентоспроможності. Відповідно процес фрормування сильного бренду $\epsilon$ стратегічно важливим та потребує посиленої уваги з боку власників бренду.

Коли людина рухається по вулиці серед натовпу людей, здебільшого вона не переживає жодних емоцій до кожного з оточуючих його людей. Однак, варто з'явитись у цьому натовпі знайомій для нього людині, як закономірно відбуватиметься певна емоційна та відповідна фрізична реакція людини. Така реакція залежить від досвіду спілкування у минулому з цією людиною та отримані враження від попередніх контактів із нею. Таким самим чином, споживачі реагують на одноманітні товари, які представлені на полицях магазину. Сама товарна маса не призводить жодного враження на людину до тих пір, доки у поле зору не попадає відомий для нього продукт або бренд. Позитивні враження, сорормовані у минулому, підштовхнуть до здійснення вибору на користь даного продукту, а негативні - призведуть до зворотного есректу. Бути конкретним і неповторним, запам'ятовуючим та надійним - це найважливіше для того, аби бренд міг з найбільшим результатом вплинути на цільову аудиторію. Маючи міцний фрундамент, можна ненав'язливо маніпулювати смаками різних сегментів ринку, створювати бажанням отримати популярний та затребуваний продукт.

Висновки. Підсумовуючи, слід зазначити, що за нестандартних умов господарювання, які створилися під дією COVID-19, успішними залишаються ті бренди, які: фокусуються на чітко обраній цільовій аудиторії та встановлюють тісний зв'язок з нею; націлені на задоволення нових запитів обраної цільової аудиторії; створюють товари і надають послуги які $\epsilon$ результатом спільної творчої співпраці 3 цією авдиторією. Власники бренду повинні досконало знати своїх споживачів адже проголошена ними місія, обрана стратегія, ссрормовані повідомлення про бренд повинні адаптуватися під задоволення цільової аудиторії. Під час пандемії COVID-19 ключовим завданням бренду є збереження ключових позицій на ринку, залучення клієнтів та дослідження змін споживацької поведінки. Компанії, які швидко відреагували на зміни в нестандартному середовищі зберегли ключові позиції на ринку та не втратили покупців. COVID-19 змінив погляди споживачів, тому потрібно швидко орієнтуватись на нові смаки та потреби. Аналізуючи дослідження компаній KPMG та Deloitte ми зробили висновок, що онлайн покупки стали досить популярними, тому слід інсрормувати та привертати увагу споживачів до товарів про можливість їх здійснення. Утримування наявних клієнтів та будування довгострокових відносин з ними формує емоційну прихильність споживачів.

\section{СПИСОК ВИКОРИСТАНИХ ДЖЕРЕЛ:}

1. Семенихин П. Бренд-колористика в стиле orange. URL: http://www.itctraining.ru/library/info/98 (дата звернення: 03.05.2021).

2. Мокшанцев Р. Психологія реклами. Москва : Інфра-М, 2009.

3. Карпова С. Современный брендинг : монографрія. Москва : Издательство «Палеотип», 2011. 
4. Ambler T., Barrow S. The Employer Brand. Journal of Brand Management. 1996. Vol. 4. № 3. P. 185-206.

5. Сартейн Л., Шуманн М. Люди - «начинка» бренда. Москва : Баланс Бизнес Букс.

6. Основні тенденції споживчої поведінки. URL: https://home.kpmg/ua/uk/home/media/press-releases/ 2020/07/osnovni-tendentsiyi.html

7. Дослідження «Споживацькі настрої українців у 2020 році». URL: https://www2.deloitte.com/content/dam/ Deloitte/ua/Documents/Press-release/RWD\%202020\%20UA.pdf

8. Вплив кризи на маркетингову діяльність підприємств. URL: http://www.economy.nayka.com.ua/pdf/ 6_2020/64.pdf

9. Как COVID-19 меняет потребительские привычки и влияет на тенденции в eCom? URL: https://platon.ua/ news/kak-covid-19-menyaet-potrebitelskie-privychki-i-vliyaet-na-tendenczii-v-ecom.html

10.Вплив бренду на поведінку споживачів на ринку дитячого харчування. URL: http://elar.tsatu.edu.ua/ bitstream/123456789/7799/1/\%D0\%97\%D0\%B1\%D1\%96\%D1\%80\%D0\%BD\%D0\%B8\%20\%D0\%A2\%D0\%94\% D0\%90\%D0\%A2\%D0\%A3\%202\%2837\%292018-33-39.pdf

11. The Importance of Brand Name in Consumer Decision Making with Focus on CNC Machine Tool Industry in India. URL: https://www.ftms.edu.my/journals/pdf/IJABM/Apr2015/318-333.pdf

\section{REFERENCES:}

1. Semenykhyn, P. Brend-kolorystyka $v$ style orange [Brand color in the style of orange]. Available at: http://www.itctraining.ru/library/info/98

2. Mokshantsev, R. (2009). Psykholohiia reklamy [Psychology of advertising]. Moscow: Infra-M.

3. Karpova, S. (2011). Sovremennyiy brending: monograflya [Modern branding: a monograph]. Moscow: Publishing house «Paleotype».

4. Ambler, T., Barrow S. (1996). The Employer Brand. Journal of Brand Management, vol. 4, no. 3, pp. 185-206.

5. Sarteyn, L., Shumann, M. Lyudi - «nachinka» brenda [Brand from the Inside]. Moscow: Balance Business Books.

6. Osnovni tendentsii spozhyvchoi povedinky [The main trends in consumer's behavior]. Available at: https://home.kpmg/ua/uk/home/media/press-releases/2020/07/osnovni-tendentsiyi.html

7. Doslidzhennia «Spozhyvatski nastroi ukraintsiv u 2020 rotsi» [The research "Consumer's mood of Ukrainians in 2020»]. Available at: https://www2.deloitte.com/content/dam/Deloitte/ua/Documents/Press-release/RWD\%20 2020\%20UA.pdf

8. Vplyv kryzy na marketynhovu diialnist pidpryiemstv [The crisis impact on the marketing activities of enterprises]. Available at: http://www.economy.nayka.com.ua/pdf/6_2020/64.pdf

9. Kak COVID-19 menyaet potrebitelskie privyichki i vliyaet na tendentsii v eCom? [How COVID-19 is changing consumer's habits and influencing trends at eCom?]. URL: https://platon.ua/news/kak-covid-19-menyaet-potrebitelskie-privychki-i-vliyaet-na-tendenczii-v-ecom.html

10. Vplyv brendu na povedinku spozhyvachiv na rynku dytiachoho kharchuvannia [The brand influence on consumer's behavior in the baby food market]. Available at: http://elar.tsatu.edu.ua/bitstream/123456789/7799/1/\%D 0\%97\%D0\%B1\%D1\%96\%D1\%80\%D0\%BD\%D0\%B8\%20\%D0\%A2\%D0\%94\%D0\%90\%D0\%A2\%D0\%A3\%20 2\%2837\%292018-33-39.pdf

11. The Importance of Brand Name in Consumer Decision Making with Focus on CNC Machine Tool Industry in India. Available at: https://www.ftms.edu.my/journals/pdf/IJABM/Apr2015/318-333.pdf 